\title{
Trump's Base, Ahab, and the American Dream
}

\author{
Inez Martinez
}

\begin{abstract}
This transdisciplinary study argues that the fury of President Trump's base can be understood as a victim complex, one caused by the erosion of the dominance of white males that existed at the founding of America. The preamble of the Declaration of Independence became an iconic articulation of the American dream, unintentionally establishing a contradiction between the ideas that all people are created equal and that individuals have an unlimited right to pursue happiness. Analysis of Ahab of Herman Melville's Moby-Dick reveals connections between Ahab's victim complex and the behavior and attitudes of Trump's base. Analysis of Ishmael's survival suggests ways the American dream as articulated in the Declaration of Independence needs to be dreamed forward. His survival through interdependence and an embrace of diversity suggests a way to re-vision the American dream so as to incorporate psychological determinants, including the limitations of the ego, in the understanding of freedom and happiness. Revisioning the individual pursuit of happiness as limited by the common good furthers the dream of equality under the law and could help free white supremacists from their entrapment in a victim complex convincing them of their entitlement to dominate others.
\end{abstract}

Keywords: victim complex, Trump's base, Ahab, American dream, white supremacy, individualism

Televised images of supporters of candidate and now President Donald Trump at his rallies shock: their glee at his hateful characterizations of non-whites, the hatred in their anti-Clinton chant, "Lock her up!," their violence against protestors at Trump's urging, and their fascistic adulation of Trump's grandiosity as he claims to be the way to "make America great again"- these images of fury unleashed demand to be understood. Why are these people so exultantly rageful?

Commentators' most sympathetic analysis has been that people in Trump's predominantly white (Henley) base feel left out, left behind, particularly economically. ${ }^{1}$ Economic loss alone, however, seems too rational an explanation. Charles Homans, political editor for The New York Times Magazine, describes the economic loss being experienced by the white middle class as a receding of the American dream. Post-Jungian theorist Tom Singer surmises that the most furious of Trump's supporters are "people who previously saw themselves as having a solid place in American society [who] now find themselves marginalized and drifting downward - both socially and economicallyor as never having had a chance of making progress toward the American dream" (37). He further defines Trump's representation of the American dream as "the materialistic power version" (41). These connections between some loss and the American dream seem to me key to understanding the ferocity of Trump's base. His followers seem emotionally caught in what clinical psychologist Elizabeth Mika, citing sociologist 
Michael Kimmel, calls "aggrieved entitlement" (306). ${ }^{2}$ Using the post-Jungian language ascribing complexes to groups in cultures (Singer and Kimbles), I postulate that Trump's followers, feeling themselves denied an entitlement promised by the American dream, are gripped by a victim complex.

The American dream is given its most iconic voice in the "self-evident truths" affirmed toward the beginning of the Declaration of Independence. There, as American children are taught in history classes, America declared itself a nation free of its colonial master and further declared its citizens - created equal - entitled to God-granted rights. The thirteen colonies proclaimed: "that all men are created equal, that they are endowed by their Creator with certain unalienable Rights, that among these are Life, Liberty, and the pursuit of Happiness." This assertion of equality was much more comprehensive than the then-existing or ensuing enactment. In young America, the power of the white father was unequaled. It was even more extensive than in Europe. J. Weiss in her article on fathering and fatherhood in colonial America points out that "English colonists expanded on the English laws and practices of family government, creating fathers who were among the most powerful household heads in the Western world, largely because of their control of the labor of subordinate household members, children, servants, and slaves" (351). Even more empowering to patriarchal white male supremacy than family structure was the contradiction between claiming that all men are equal while institutionalizing slavery in the U. S. Constitution and in the American economy. The Constitution included chattel slavery among its considerations of representation and taxation. Chattel slavery meant that whites could buy, own, chain, work, whip, rape, maim, and even, if the white owner wished, kill black African slaves stolen from their homeland and then bred for profit. This contradiction led not only to the Civil War, but also to the continued assumption of white supremacy that informs the victim complex of Trump's supporters today.

Surprisingly, the Index of Carl Jung's Collected Works contains not a single entry under "victim." Jung, Sigmund Freud, James Hillman, and many others have explored literary works as a primary source for understanding psyche, a practice that Susan Rowland has elaborated as an instance of transdisciplinarity (3). When I turn to imaginative literature to seek understanding of an American victim complex, the enraged Ahab of Herman Melville's profoundly American novel, Moby-Dick, springs to mind. Ahab, consumed with fury at having suffered dismemberment by a creature he assumed was his to capture and dismember, personifies being enslaved to a victim complex.

Edward F. Edinger, in his extensive study of Melville's novel, calls Ahab "a primordial image that lie[s] deep in the American soul" (27). Both he and Jungian critic James Kirsch see in Ahab a journey toward the Self but disagree about the success or failure of the journey. Edinger concludes that Ahab with the words, "Thus I give up the spear!" (136), successfully surrenders his ego to the greater Self and that his death, tied to the whale as to the Great Mother, represents a coniunctio (56). Kirsch concludes the opposite, that the collision between Ahab and the whale represents Melville's own failure in the individuation journey (54-74). I share neither of these conclusions ${ }^{3}$ but do agree that the issue of the individual ego and its relation to that which is greater than itself is central to Ahab's character, and thus to understanding how his obsession with having been victimized sheds light on the fanaticism of Trump's supporters. Ahab's relentless 
assertion of his will against a force of nature, the white whale, reveals the underbelly of the American claim of a limitless right to pursue happiness and exposes the grandiosity of the ego's search to assert such power regardless of consequences to others. Ahab's vendetta provides a grim warning about American individualism conceived as unlimited by the common good.

The perception of the specifically American quality of Ahab's character and fate has been echoed throughout the criticism of Moby-Dick, ${ }^{4}$ persistently focusing on the implications of American individualism. The American literary historian F. $O$. Matthiessen, for example, writes: "Melville created in Ahab's tragedy a fearful symbol of the self-enclosed individualism that, carried to its furthest extreme, brings disaster both upon itself and upon the group of which it is a part" (79). Sacvan Bercovitch in his intellectual history of American literature also sees the destruction of the monomaniacal Ahab as an argument for the containment of individualism (193). Harold Bloom, editor of the anthology of criticism of the character, Ahab, writes in his introduction that "Ahab's quest is supremely American because its God is identical with the inner self." (4). Through the character of Ahab, Melville depicts the inflation of the American claim of the unqualified right to pursue happiness and the catastrophe that follows upon the vengeance born of the inevitable thwarting of that claim. This paper argues that members of Trump's base, psychological inheritors of the privileges accorded white people-in particular white males - at the founding of the country, exhibit Ahab-like rage at the loss of presumed rights to dominance. It argues further that this sense of entitled outrage is rooted in the founding American dream, which failed to qualify individual rights with responsibility for the common good.

Ahab, a white male American, dramatizes entitlement to supremacy as a ship's captain. His ship, the Pequod, is peopled with humans from all over the globe, including the harpooners Queequeg from the South Sea Islands; Daggoo from Africa; and Tashtego, a Native American from Martha's Vineyard. Melville describes the crew as "An Anarcharsis Clootz deputation," referencing Jean Baptiste Clootz who in 1790 took to the French National Assembly a "deputation of foreigners whom he had picked up in Paris, thus dramatizing the sympathy of all mankind with the French Revolution" (166n). Melville's careful rendering of the spectrum of colors of humanity serving under the authority of Ahab represents the hierarchy of white male supremacy, a hierarchy even applying to white on white since Ahab masters his white officers and crew members as well.

Even with the unlimited powers of a captain at sea, however, Ahab experiences himself as a victim. Instead of being turned into whale oil, the white whale Moby Dick turns Ahab into a one-legged man, a suffering of humiliation even more infuriating than the actual loss of the leg. Ahab both literally and figuratively no longer has the leg of entitled supremacy to stand on. Suffering, of course, happens to everyone. What makes someone experience suffering as victimization? A defining characteristic of feeling victimized is resentment, an emotion, as Edinger notes, possessing Ahab (67-8). The entire whaling industry existed on the premise that nature is to be man's prey, not his master. ${ }^{5}$ Ahab, captain of his ship, an image for being in control of his life, personifies the American mythology of individualism. That is why he fulminates against fate's permitting his rightful prey to turn on him, rip his good leg right out from under him, and 
win. He can tolerate no challenge to his control. Confronting first mate Starbuck's temerity in questioning him, he insists, "There is one God that is Lord over the earth, and one captain that is lord over the Pequod" [sic] (604). The loss of control over his life because of a powerful external force such as a whale resisting its hunters excites righteous resentment in Ahab, a response signifying his sense that successful opposition is an injustice. Trump's base exhibits comparable outraged resentment. Their resistance to Mexicans and Muslims, for example, is based on an assumption that America is theirs. As Ahab is entitled to kill whales, they are entitled to eject and reject non-white immigrants. The fact that Mexicans keep coming to America and that Muslims live here as citizens violates their assumed right to the land and culture of America. As Ahab roused his crew to right the wrong of Moby Dick's existence, they ecstatically support the ideas of barring all Muslims from America and building a literal wall to keep Mexicans out.

But what turns experiencing suffering as victimization into a complex? A characteristic of any complex is its compulsiveness. Ahab presents himself as utterly incapable of making any choice other than to pursue Moby Dick to the death. He protests:

What is it, what nameless, inscrutable, unearthly thing is it, what . . . hidden lord and master, and cruel, remorseless emperor commands me; that against all natural lovings and longings, I so keep pushing, and crowding, and jamming myself on all the time; recklessly making me ready to do what in my own proper, natural heart, I durst not so much as dare? (685)

The replacement of normal ego control by a complex is also revealed in the failure of Ahab's experience to persuade him to reconsider his mission of vengeance. After having survived a second day of giving chase to Moby Dick, which saw all three boats smashed, their crews tossed into the sea, and Ahab's whalebone leg splintered, Ahab has reason and time to alter course. The morning of the third day, as he directs the helmsman to follow Moby Dick's wake, he finds himself responding to the freshness of an exquisite dawn. He says, "What a lovely day again! Were it a new-made world, and made for a summer-house to the angels, and this morning the first of its throwing open to them, a fairer day could not dawn upon the world' (709). He almost considers how such a fair day might be lived, but resisting even the thought of doing anything but hunting Moby Dick, he cries out: "Here's food for thought, had Ahab time to think; but Ahab never thinks; he only feels, feels, feels" (709). Since throughout all the chapters in which he appears, Ahab is almost obsessively analytical and reflective, this line about being overwhelmed with feeling underscores the power of the complex to control in spite of Ahab's proven capacity for thought.

That kind of power seems operative in the unfazed support of Trump's base in the face of Trump's violating his campaign promises by his turning the cabinet into a plutocracy rather than "draining the swamp," his demanding tax dollars to build the border wall rather than having Mexico pay for it, and his giving tax breaks to the most wealthy at the expense of health care for any of his supporters who happen to be old, poor, or very sick. No matter how much his practices belie his words, the facts and reason do not sway his supporters' behavior, evidence of its compulsive nature. 
That Ahab's response of self-righteous rage is characteristically American is made clear in the chapter in which Ahab's ship, the Pequod, meets the British ship, the Samuel Enderby. ${ }^{6}$ This encounter also dramatizes Ahab's loss of power through his having been crippled. Understanding that the Samuel Enderby has encountered Moby Dick, Ahab rushes to visit its captain, an impetuous move that results in his realizing the ignominy of his inability to climb to the deck. Cables have to be lowered to bring him on board. This incident is one of Melville's more poignant portrayals of Ahab's hatred of dependence. His loss of his leg has brought home to him that vulnerability is part and parcel of having a body. He expresses his disgust over this limitation when, after losing his whalebone leg on the second day of the chase, the same leg as was ripped from him as flesh, he cries, "'Oh, oh, oh! How this splinter gores me now! Accursed fate! That the unconquerable captain in the soul should have such a craven mate! . . My body" (705). The inflated fantasy of unlimited freedom and power, presumed birthright of the white American male, is punctured by the limitations of having a body liable to being wounded. Ahab's response is to curse this fate. Similar rage over a frustrated fantasy attempting to empower the body, the fantasy that its whiteness should guarantee dominance, erupts in enraged white supremacist protests, such as the march in Charlottesville held by neoNazis emboldened by Trump's racism.

Once on deck of the Samuel Enderby, Ahab presses its captain for the story of his encounter with Moby Dick, an encounter that took the captain's arm. He and Ahab greet one another by crossing a whalebone arm and a whalebone leg. When Ahab hears that the Samuel Enderby has twice more crossed paths with Moby Dick, he is flabbergasted to learn that the captain did not give chase. The British captain responds: "'ain't one limb enough? What should I do without this other arm?'" (563). What the British captain lacks is the American individual's sense of a right to control over his life.

Deprived of that control, Ahab feels entitled not only to destroy what he sees as the agent of the universe's maleficent power, the white whale, who made a mockery of his pose of control, but also to convert those he is responsible for, his crew, into participating in his mission of hate. His sense of entitlement is much like that of the white supremacists, misogynists, and nationalists who seek converts to their hatred of black people's, women's, and immigrants' - particularly Muslim immigrants'-having rights when white men, white women, and Christians are not in control of their lives and successfully achieving happiness. Cal Jillson attributes the acquiescence of Ahab's crew to democracy's vulnerability to tyranny through the "moral failings" of the people (95$6)$.

Ahab's character reveals that an American formula for feeling victimized and justified in behavior both vindictive - "Lock her up"-and violent - "Get them out of here. Knock the crap out of them" (White) - eventually manifests in a collective ecstatic expression of hate. The power fantasy embedded in the American Dream that one need not be concerned about any harm done to others in the free pursuit of one's happiness is based on denial of being responsibly connected to others. The fate of the Pequod under the possessed Ahab, its destruction and disappearance in the ocean's waters, which connect all places and all their inhabitants, is emblematic of the flaw in the American dream of individual entitlement. Precisely the failure of that dream to include awareness of interdependence lies behind Trump supporters' backing of denigrating international 
cooperation through NATO; of pulling out of the Paris Accord, which tries to ameliorate human effects upon the life systems of the earth; and of building a wall to keep others out.

The part of the Declaration of Independence and the American dream that is anathema to Trump's base is the clause stating that all people are created equal. America's gradual progress toward realizing the equal rights of all human beings - the emancipation of the slaves, the gradual extension of the power to vote to all American citizens of sufficient age, and the redefining of women's roles and of what constitutes family-renders equal, rather than superior, people who had experienced dominating others as a birthright bestowed by maleness and whiteness. The Women's Studies scholar, Peggy McIntosh, in her ground-breaking essay on the powers granted whiteness and maleness details many ways that race and gender determine the unconscious experience of dominance. McIntosh, based on her understanding of how males are unaware of the culturally systemic ways they effortlessly enjoy dominance, discovers analogously forty-six unearned powers and protections she enjoys by being white. The erosion of the culturally bestowed privileges of whiteness accounts for the Ahab-like fury at authority expressed by Trump's base, many of whom are white women. While propertied white males have from the beginnings of America been granted power over others through both their gender and their race, white women have enjoyed the cultural privileges of whiteness. In particular white wives and mothers have benefited from the culturally accorded privileges enjoyed by their white husbands and sons. The white supremacists, male and female, in Trump's base have targeted government run by liberals and by women who think to rule, forces that legalized the changes that have eaten away at their privileged place in the social hierarchy. Some of them, like white nationalists, paramilitary militias, and lone terrorists, countenance and sometimes enact violence, practices of hatred that Trump has affirmed as arising from "good people" in his response to the neo-Nazi violence in Charlottesville (Keneally).

Those supporting Trump because of the loss of white dominance apparently value unlimited power. They accepted his attitude toward use of nuclear power when, as a candidate, he asked, why have nuclear weapons if not to use them? (Zurcher). His repeated declarations during rallies that he would support not only waterboarding, but worse tortures, thus violating the Geneva Conventions, were greeted with roars of approval. Their belief in rule by threat of violence continues the long American tradition of using oppressive power to enrich ourselves. Under white-male dominated governments, despotic power has been legalized in the U.S. Constitution's acceptance of slavery, in the occupation and westward expansion of the country over the bodies and cultures of indigenous peoples, in anti-labor laws, in legally granting corporations privileges of persons, and in equating money with free speech. In their devotion to power unchecked by laws seeking the rights of all, Trump's white supporters are like Ahab's crew who are caught up in Ahab's claim of ultimate authority. Maurice Friedman points out that Ahab goes even beyond Aeschylean Prometheus in his claim to have no power over him, in particular no superior arbiter of truth: "Ahab arrogates to himself all the authority of truth." (86). Trump's similar arrogation when he Tweets what Kellyanne Conway terms "alternative facts" feeds the complex entrapping his base. They, like Ahab's crew awed by Ahab's grasping the harpoon lit by lightning and defying the 
corposants burning atop the Pequod's masts, submit to Trump's authority out of their own fantasy of a leader who will impose upon the world his will to power, which mirrors their own.

Ahab's will to power implicitly reveals the tyranny contained in a desire for limitless freedom, an insight expressed by literary critic Michael Paul Rogin, citing Michael Gilmore: "[Ahab] reveals the rebellion and the desire for domination entangled in the wish to be free" (130). ${ }^{7}$ Trump's attacks on "political correctness," that is, on the repression of the sense of entitlement to dominate others, indicate the kind of freedom his base desires. His mockery of the disabled, his claims of the right sexually to assault women, and his exhortations to violence against opponents, model "freedom" as dominance by the physically strong and culturally privileged. It is this version of "freedom" that his base, particularly his white male base, wishes to have resurrected in their support of his mantra, "Make America great again."

The conclusion of this novel anticipates the end awaiting the ship of state of a people pursuing, as a birthright, happiness without concern for the good of others. That mindset leads to hating to pay taxes for the common good-for helping others get education, health care, clean air and water. It leads to seeking privileged lifestyles flagrant with consumption at the price of planetary degradation. It leads to feeling victimized when the culturally spawned illusion of being superior and entitled to subordinate others to one's use erodes. That loss of culturally legitimized white supremacy is the volcanic power behind the eruption of rage and hate expressed by followers of Trump during his campaign. The Pequod's slow, swirling descent into the depths of the ocean augurs the fate of American society if the victim complex of white supremacists continues to control the ship of state.

The tragic drowning of the captain and crew of the Pequod has been interpreted by historian of the American dream, Cal Jillson, who cites Frederic Carpenter before him, ${ }^{8}$ as Melville's criticism of the American dream. Both Carpenter and Jillson assert that Melville ascribes Ahab's obsession and his failure to fate (97). Melville's fatalism, Jillson claims, leads to a belief in life's futility. He offers the following text as illustrative of Melville's giving no credence to the hopes of the American dream: "The world's a ship on its passage out. . . . One most perilous and long voyage ended, only begins a second, and a second ended,, only begins a third and so on, for ever [sic] and for aye. Such is the endlessness, yea, the intolerableness of all earthly effort." Jillson comments, "So much for the humanism of Jefferson ..." (97). Melville actually provides conflicting attitudes toward fate and free will in Moby-Dick through not only placing various points of view in different characters, but by describing different viewpoints held by the evolving narrator, Ishmael. Ishmael begins his journey in a mood of angry dissatisfaction with life. He explains his decision to take to the sea again as an effort to cope with his foul feelings:

Whenever I find myself growing grim about the mouth, whenever it is a damp, drizzly November in my soul, whenever I find myself involuntarily pausing before coffin warehouses, and bringing up the rear of every funeral I meet; and especially whenever my hypos get such an upper hand of me, that it requires a strong moral principle to prevent me from deliberately stepping into the street, and methodically knocking people's 
hats off - then I account it high time to get to sea as soon as I can. This is my substitute for pistol and ball. (23)

It was in this self-destructive state of mind that Ishmael voices the words Jillson uses to confirm his belief that Melville is fatalistic. Actually, Ishmael is the character Melville uses to convey hope of an alternative to Ahab's rage.

Before choosing a ship, Ishmael is confronted with a human being who at first glance seems very unlike himself. In a series of humorous chapters, Melville recounts Ishmael's encounter with a cannibal from the South Seas, beginning with Ishmael's finding himself sharing a bedroom and a bed with him. At first Ishmael is terrified of the alien aspect of this stranger covered in tattoos and smoking a tomahawk pipe. Then as he watches him sacrifice a bit of biscuit to his idol, perform his morning ablutions, eat breakfast at a common table, take a calm, after-breakfast smoke, and leaf through a book he apparently could not read, Ishmael, no longer afraid, begins to think this South Sea Islander named Queequeg a fine fellow. He muses to himself:

With much interest I sat watching him. Savage though he was, and hideously marred about the face — at least to my taste - his countenance yet had a something in it which was by no means disagreeable. You cannot hide the soul. Through all his unearthly tattooings, I thought I saw the traces of a simple honest heart; and in his large, deep eyes, fiery black and bold, there seemed tokens of a spirit that would dare a thousand devils. And besides all this, there was a certain lofty bearing about the pagan, which even his uncouthness could not altogether maim. . . . It may seem ridiculous, but [his brow] reminded me of General Washington's head .... Queequeg was George Washington cannibalistically developed.

Reflecting on Queequeg's self-sufficiency, Ishmael is moved to admiration, even awe. Calling Queequeg's self-possession "almost subline," Ishmael thinks, "Here was a man some twenty thousand miles from home, by the way of Cape Horn . . . thrown among people as strange to him as though he were in the planet Jupiter; and yet he seemed entirely at his ease; preserving the utmost serenity; content with his own companionship; always equal to himself" (83). As Ishmael and Queequeg become friends, they decide to ship out together and take a packet schooner to Nantucket to find a ship. On board, while Queequeg smokes his pipe, a country bumpkin makes fun of him behind his back. Queequeg discovers him, picks him up, tosses him in the air, and then taps him so he lands on his feet. The fellow runs to the captain, but as he does so, the rope holding the boom breaks loose, and the swinging boom knocks him overboard. While all on board panic, Queequeg, on his knees, takes a rope, secures it, and lassoes the boom. Then he takes off his shirt, dives into the freezing water, and saves the man who had mocked him. That done, he asks for some water to wash off the brine, returns to his pipe, and "leaning against the bulwarks, and mildly eyeing those around him, seemed to be saying to himself - 'It's a mutual, joint-stock world, in all meridians. We cannibals must help these Christians." Queequeg's magnanimity models awareness of human interdependence, the awareness and magnanimity missing from the individual pursuit of happiness without regard for others. 
Ishmael's gradual transition from terror at the appearance of his strange bedfellow to recognition of him as a man, then as a brave and honest man - then even more than that - as an extraordinarily philosophical man, one who calls up the visage of the first president of the United States, suddenly frees him of his dark mood. He says he "began to be sensible of strange feelings. I felt a melting in me. No more my splintered heart and maddened hand were turned against the wolfish world. This soothing savage had redeemed it" (83). Recognizing the humanity of Queequeg and befriending him transforms Ishmael's misanthropy.

Queequeg also indirectly becomes the means of society's learning about Ahab's tragic enslavement to his victim complex. Before sailing on the Pequod, Ishmael attended a sermon on the story of Jonah given by an ex-sailor, Father Mapple, during which Ishmael was taught that a man must speak truth to fulfill God's will and his own life. Ishmael's recounting of the story of the Pequod's journey and destruction is his fulfillment of this injunction. Queequeg is the reason he was able to survive and tell the tale. During the voyage, Queequeg had become ill and ordered that a coffin be made for him. Instead of dying, however, he recalls an undone duty and through strength of character regains his health so that he might perform it. When the ship loses its life-buoy, Queequeg suggests that his coffin be turned into one. Ahab muses on the possibility that a conveyer of the dead might be made into a conveyer of life, but rejects the thought: "A life-buoy of a coffin! Does it go further? Can it be that in some spiritual sense the coffin is, after all, but an immortality preserver? But no. So far gone am I in the dark side of earth, that its other side, the theoretic bright one, seems but uncertain twilight to me" (666-67). After Moby Dick rams the Pequod, Queequeg's coffin-life-buoy is ejected from the vortex of the sinking ship. Ishmael grabs onto it and is eventually picked up by a ship looking for a lost child. Through the conveyor of death, the coffin-turned-life-buoy through the character and suggestion of his cannibal friend, Ishmael survives the sinking ship. Because a member of the whaling community, the captain of the Rachel, searches for his lost son, Ishmael is picked up and survives being cast adrift in the ocean. Relatedness, interdependence, and care for those in need is Melville's alternative to Ahab's dying locked in a victim complex of vengeful rage. Melville clearly portrays the danger to the collective of psychological entrapment through the character of Ahab, but he also offers a parable of hope through the character of Ishmael.

The characters and fates of Ahab, Ishmael, and Queequeg suggest that the collective response to the rage of Trump's supporters needs first to bring to consciousness the psychological dynamics operating unconsciously in those caught in a victim complex, and second, to explore the changes in attitude and understanding that could help free those so caught. The sense of privileged entitlement to pursue one's happiness at the expense of others requires deepening collective understanding of happiness beyond an ego perspective, that is, beyond the demand to have personal desires satisfied. Religions such as Buddhism teach that living for satisfaction of desires is actually a source of suffering rather than happiness. Having goals that do not suffice to bring happiness, Americans defer happiness, whatever that may be, to the lives of our children generation after generation. Not having achieved happiness, however hard it has been pursued, Americans are vulnerable to scapegoating others for their lack of it, as Trump's supporters scapegoat those who are not white. A more realistic understanding of 
happiness requires a less ignorant understanding of psyche. At the least, it requires recognition of the limits of the ego and of ego gratification.

Human freedom is inherently limited psychologically by the power of unconsciousness, including its form as ignorance, to take control of consciousness unbeknownst to the ones being taken over. Mobs offer a familiar collective example. Recognizing that consciousness is subject to possession by aspects of unconscious psyche reveals the terrain in which the possibilities of psychological freedom exist. Becoming aware of unconscious enslavement in a complex, such as a victim complex, for example, is potentially a first step toward breaking free of obsessive emotions such as hatred and vindictiveness. Choices about responses then become possible. That recognition may open the way to a level of psychological freedom enabling a kind of happiness that arises from the experience of meaning, perhaps eventually including the meaning of pursuing the well-being of others as well as of oneself. Pl depends upon increased psychological freedom. Pursuit of psychological freedom requires changing one's relationship to the unconscious psyche from being controlled to being nourished by it. Recognizing the nourishing power of the unconscious psyche can help depotentiate a complex. It is through symptoms provided by the unconscious psyche, for example, that one can gradually come to know oneself and thus move from identifying with one's ego ideal to living more authentically as who one is. Thoughts and feelings arising from the unconscious psyche to consciousness can offer freeing insights and life-enriching emotional ties. The greater psychological freedom and fulfillment enabled by these offerings of the unconscious psyche can stir gratitude, a kind of happiness grounded in receptive relationship. The ego's relationship to the unconscious psyche can move from being unconscious captive to conscious beneficiary and willing exponent. That is, the unconscious psyche is thereby provided living manifestation in conjunction with human choice.

Merely naming these ideas does not communicate knowledge of the realities the ideas represent. But at least the concepts can have a public life that individual experience may infuse with meaning. If Jung is correct in claiming that unconsciousness longs for consciousness and that consciousness is nourished by the "deep wells of being" seeking consciousness ( $C W 5$, par. 299), then the surfacing of the victim complex based on the white supremacist individualism embedded in American history can be seen as an opportunity for the nation to deepen its understanding of freedom, happiness, and relatedness. Recognizing the complex potentially serves a collective re-visioning of the American dream.

It is morally obligatory, however, not to equate kinds of victimization. The sense of being victimized because one has lost culturally bestowed privileges to oppress others is not the same as being victimized, for example, by being put into sexual slavery. Both could lead to entrapment in responses characteristic of complexes. But victimization as loss of oppressive privilege requires having its rage and vengeance recognized as in need of moral transformation. As Jung writes, humans are moral by nature: "Moral law is nothing other than an outward manifestation of man's innate urge to dominate and control himself' ( $C W 4$, par. 486.) Victimization caused by oppressive power must be resisted and its destructive effects on victims' psyches addressed. 
Addressing the cultural victim complex of Trump's supporters not only has the virtue of seeking a more moral American society; it also promises more psychological freedom for the supporters, themselves. Suffering a complex is a kind of enslavement, much like that suffered by Ahab and his crew. Melville writes: "all the individualities of the crew, this man's valor, that man's fear; guilt and guiltlessness, all varieties were welded into oneness, and were all directed to that fatal goal which Ahab their one lord and keel did point to" (701). Melville specifically refers to this relationship between leader and followers as one of enslavement. He writes: "their hearts were bowled along. The wind that ... rushed the vessel on by arms invisible as irresistible; this seemed the symbol of that unseen agency which so enslaved them" (700). As portrayed by the Pequod's drowning crew and Ahab's crucifixion roped to the diving Moby Dick, being caught in a lust for power dooms the enslaved eventually to being overpowered and dragged to death in unconsciousness. Addressing the cultural victim complex of white supremacists offers them hope of liberation while also focusing all Americans on creating a more moral version of the American dream.

Jung warns of the dangers that arise when a nation relinquishes hopes of its own morality, hopes which for Americans have been manifested in seeking to develop a society in which the equal rights of all people are realized. Jung writes, "We have had bitter experience of what happens when a whole nation finds the moral mask too stupid to keep up. The beast breaks loose, and a frenzy of demoralization sweeps over the civilized world" ( $C W 5$, par. 341). Trump's followers are caught in a victim complex rushing them on an unreasoning mission to support Trump's resurrecting America's founding dominance of propertied white males. In the unpredictable ways of psyche's evolution, the American enactment of free pursuit of one's happiness at anyone's and anything's expense has led to a psychological complex threatening to sink the American ship of state - or to provide the impetus to address the unbridled individualism of the American dream by reconceiving it.

While working at concluding this paper, I had a dream about a "State-of-words." Reflecting on the phrase, I thought of the preamble to the Declaration of Independence as a State of words comparable to the governing state - an imaginal State-of-words. I thought of its declaration of rights defining the dream of America for all people as an imaginal realm demanding to be dreamed on. History reveals that process has been ongoing since the beginning. The covenants of the Puritans and Quakers provided a spiritual background for the version created by Benjamin Franklin through his characters Father Abraham and Poor Richard. As Jillson notes, "Franklin taught personal virtues, but men were to use them in the service of community." (36) Andrew Jackson interpreted the dream so as to extend its promised rights to all white men. Lincoln extended the right to life and liberty to slaves. Social Darwinism, which had no respect for natural rights and equality, gutted the sense of community instilled in the dream by the Puritans and Quakers. After decades of an economy dedicated to the survival of the fittest, Theodore Roosevelt declared that should there be conflict between the rights of property and those of man, the rights of man should prevail (Jillson 163). The suffrage movement led to applying the idea of equal rights to women. Franklin Delano Roosevelt claimed to revise the dream in terms of the then existing economic order. Martin Luther King led a nonviolent movement to realize the dream of freedom for black Americans rooted, as he said, 
"deeply in the American dream." After John Kennedy's assassination, Lyndon Johnson successfully negotiated the promise of equal rights to blacks into law. This evolving revisioning of the State-of-words of the American dream continues as America changes. The surfacing of the hatred of Trump's base suffering the victim complex of lost entitlements calls for articulating moral limits to the right of individuals to pursue their happiness. Franklin Delano Roosevelt recognized this need when, discussing the right to pursue happiness, he said that "we know that liberty to do anything which deprives others ... is outside the protection of any compact" (Jillson, 175). Yet he did not specifically add this recognition to the State of words encapsulated in the Declaration of Independence.

Using the insights gained from Ishmael's experiences and the suggestion of my dream, that is, insights gained from sources infused by unconscious materials, I suggest the following revision of the imaginal State-of-words of the American dream:

The fifty states proclaim: That all people are created equal, that we as a people are endowed by our human moral imagination with certain unalienable Rights, that among these are Life, Liberty, and the individual pursuit of Happiness, providing that pursuit does not harm the rights of any other or the good of all.

There is much in the possible moral imagination of the good society that is not included here, but some key ideas are present. The imaginal state envisioned by that wording places individuals within a context of being a people. It respects the rights to religious beliefs of all by not specifying any. It asserts the role of human imagination in the creation of culture. And it limits individual pursuit of happiness by prohibiting harm to individuals or to the common good. Such a revision of the State-of-words repudiates white supremacists' ego dream of power over others and frees them of a sense of entitlement to that power. It does so while continuing to embrace the moral dream of justice in the proclamation that all of us share equal rights to life and liberty contained in the original declaration.

In summary, the diminution of the white male supremacy institutionalized during the founding of America underlies the victim complex of Trump's supporters. Analysis of Ahab's victim complex and of Ishmael's survival suggests that part of what is needed to break free of that complex is people befriending the culturally alien other and caring for one another. These realizations call for revising the limitlessness of the individual's right to pursue happiness as implied in Jefferson's phrasing of the American dream internalized by subsequent generations. They lead to adding a prohibition of harming others to our understanding of the American right to pursue happiness. That revision introduces the common good to the understanding of the American dream.

\section{Contributor}

Inez Martinez, Ph.D., professor emerita of literature, writes psychological criticism of literature. Her publications include studies of literary works by authors illuminating Hero and Beauty archetypes (Radclyffe Hall), the emergence of Self (Kate Chopin), integration of personal shadow (Joseph Conrad), personal transformation of racist cultural shadow (James Baldwin), limitations of ego readings, numinosity in readings, Oedipus' legacy of 
rejecting responsibility, experience of psyche in matter (Isak Dinesen), and a cultural mother complex issuing from slavery (Toni Morrison).

\section{Notes}

${ }^{1}$ See, for example, Thomas Frank's Listen, Liberal, which argues that the Democratic Party has abandoned its working-class base.

${ }^{2}$ Mika cites Kimmel's Angry White Men: American Masculinity at the End of an Era, Nation Books, 2013.

${ }^{3}$ Edinger's reading of the words "I give up the spear" as a transformative reconciliation of Ahab's ego to the greater Self ignores not only his intention to kill the white whale but also the unrepentant context in which his words are spoken: "Towards thee I roll, thou all-destroying but unconquering whale; to the last I grapple with thee; from hell's heart I stab at thee; for hate's sake I spit my last breath at thee. . . . Thus I give up the spear!" Kirsch's move from the text to an analysis of the author represents a methodology that, although widely practiced, I believe flawed. Analyzing a character is possible because the form of the tale is complete and what information that can be known about the character is given. Analyzing an author through readings of his or her texts inflates those texts into a supposed understanding of the mystery of the author's lived life which encompasses much more than his or her writings.

${ }^{4}$ Melville himself began the claim that Moby-Dick represented "an elevated aspect of American life" in a letter to his English editor Richard Bentley. (Updike 124).

${ }^{5}$ In the Extracts at the beginning of Moby-Dick, Melville includes the following passage from Obed Macy's History of Nantucket: "In the year 1690 some persons were on a high hill observing the whales spouting and sporting with each other, when one observed; [sic] 'there-pointing to the sea-is a green pasture where our children's grand-children will go for bread!'” (17).

${ }^{6}$ The critic Wai-Chee Dimock notes the contrast between the Captain of the Samuel Enderby and Captain Ahab, but not in terms of contrasting European and American sensibilities. Dimock stresses the other captain's human, reasonable efforts to avoid doom (61).

7 Rogin credits Gilmore's The Middle Way: Puritanism and Ideology in American Romantic Fiction, Rutgers UP, 1977, p. 147.

8 Jillson cites Carpenter's American Literature and the Dream. Philosophical Library, 1955, pp. 74-75.

\section{Works Cited}

Bercovitch, Sacvan. The American Jeremiad. U of Wisconsin, 1978.

Bloom, Harold, editor. Ahab. Chelsea House, 1991.

— . "The Analysis of Character." Bloom, pp. ix-xiv.

- Introduction. Bloom, pp. 1-5.

Declaration of Independence. America's Founding Documents, National Archive, www.archives.gov/founding-docs/declaration-transcript.

Dimock, Wai-Chee. "Blaming the Victim," Bloom, pp. 57-62. 
Edinger, Edward. F. Melville's Moby Dick: An American Nekyia, 2nd. ed. Inner City Books, 1995. Studies in Jungian Psychology by Jungian Analysts 69.

Frank, Thomas. Listen, Liberal: Or What Ever Happened to the Party of the People? Metropolitan Books, 2016.

Friedman, Maurice. “Captain Ahab: Modern Promethean.” Bloom, Ahab, pp. 81-103.

Henley, John. "White and Wealthy Voters Gave Victory to Donald Trump, Exit Polls Show." www.theguardian.com/us-news/2016/nov/09/white-voters-victorydonald-trump-exit-polls.

Homans, Charles. "The End of the American Dream.” New York Times Magazine, 1 May 2016.

Jung, C. G. The Collected Works of C. G. Jung. General editor, Sir Herbert Read et al., translated by R. F. C. Hull, 2nd. ed., Princeton UP, 1953-1979. 20 vols. Bollingen Series 20.

Jillson, Cal. The American Dream in History, Politics, and Fiction. UP of Kansas, 2016.

Keneally, Meghan. "Trump Lashes Out at 'alt-left' in Charlottesville, Says 'fine people on both Sides."” 15 Aug. 2017. abcnews.go.com./politics/trump-lashes-alt-leftcharlottesville-fine-people-sides/story?id=235032.

King, Martin Luther, Jr. "I Have A Dream” speech, 28 August 1963. www.americanrhetoric.com/speeches/mlkihaveadream.htm.

Kirsch, James. "Herman Melville in Search of the Self." Professional Reports, 1st Annual Conference of Jungian Analysts, 1974, pp. 20-49. Rpt. in Psychological Perspectives, vol. 7, no. 1, 1976, pp. 54-74.

Matthiessen, F. O, "The Fate of the Ungodly, Godlike Man,” Bloom, pp. 69-80.

McIntosh, Peggy. "White Privilege and Male Privilege: A Personal Account of Coming to See Correspondences through Work in Women's Studies." CollegeArt.org, 1988. www.collegeart.org/pdf/diversity/white-privilege-and-male-privilege.pdf.

Melville, Herman. Moby-Dick or The Whale. 1851. Edited by Charles Feidelson, Jr., Bobbs-Merrill, 1964.

Mika, Elizabeth. "Who goes Trump? Tyranny as a Triumph of Narcissism.” The Dangerous Case of Donald Trump. Edited by Lee Bandy, Thomas Dunne books, 2017, pp. 298-318.

Rogin, Michael Paul. “Moby-Dick and the American 1848.” Bloom, pp. 124-49.

Rowland, Susan. Remembering Dionysus: Revisioning Psychology and Literature in C. G. Jung and James Hillman. Routledge, 2017.

Singer, Tom (aka Thomas). "President Trump and the American Selfie: Archetypal Defenses of the Group Spirit." A Clear and Present Danger: Narcissism in the Era of President Trump, edited by Leonard Cruz and Steven Buser, rev. ed. Chiron, 2017, pp. 17-47.

Singer, Thomas, and Samuel L. Kimbles, editors. The Cultural Complex. BrunnerRoutledge, 2004.

Updike, John. "Reflection: Melville’s Withdrawal.” New Yorker, vol. 93, no. 31, 10 May 1982, pp. 120-47. 
Weiss, J. "Fathering and Fatherhood." Encyclopedia of Children and Childhood: In History and Society, vol. 2, pp. 348-53. Macmillan Reference USA, link.galegroup.com.pgi.idm.oclc. org/apps/doc/CX3402800167/GVRL?ucarp39441\&sid-GVR\&xid=1ce97779.

White, Daniel. "Donald Trump Tells Crowd to Knock the Heck Out of Hecklers." 1 Feb. 2016, time.com/4203094/donald-trump-hecklers.

Zurcher, Anthony. "Donald Trump's Nuclear Fixation-from the 1980's to Now." 10 Aug. 2017. www.bbc.com/news/world-us-canada-40879868. 